\begin{tabular}{|c|c|}
\hline $2 x$ & Asian Social Work Journal (ASWJ) \\
\hline & Volume 3, Issue 5, December 2018 \\
\hline $\begin{array}{l}\text { ASIAN SOCCAL WORK } \\
\text { JOURNAL } \\
\text { (ASW) }\end{array}$ & e-ISSN : 0128-1577 \\
\hline 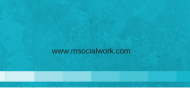 & $\begin{array}{c}\text { Journal home page: } \\
\text { www.msocialwork.com }\end{array}$ \\
\hline
\end{tabular}

\title{
Paradigm Changes of Pesantren: Community Based Islamic Scholar Perception About Post-Modernism Pesantren Based on Android
}

\author{
Prima Aswirna ${ }^{1}$, Reza Fahmi ${ }^{1}$, Ahmad Sabri $^{1}$, Darni Yusna ${ }^{1}$ \\ 1Universitas Islam Negeri Imam Bonjol Padang \\ Corrrespondence: Prima Aswirna (primaaswirna@uinib.ac.id)
}

\begin{abstract}
Pesantren is the forerunner of education based in Indonesia. This study uses a quantitative approach. Population in this research is Padang city society (especially in District of Padang Utara). The study sample was 128 people and 30 community leaders (Alim-Ulama) people. The sample selection was done by simple random (simple random sampling). Data collection techniques using questionnaires. Data analysis technique using SPSS program version 24. Statistical analysis technique used is Pearson correlation. The results of the study found: there is no correlation between public opinion and religious figures about the development of pesantren based on android postmodernism. Recommendations: There needs to be a more in-depth study of the development of Android-based pesantren at the empirical level; curriculum, learning system, learning strategy and assessment mechanism and so on.
\end{abstract}

Key words: pesantren, society of post-modernism, virtual pesantren and android

\section{Introduction}

Education is an integral part of the life of the nation and state. One of the factors that will improve the quality of life is to improve the quality of education. It shows that the quality of education is very determining the quality of life of the nation and state. Improving the quality of education is a commitment to improving the quality of human resources, both as individuals and as the basic capital of nation-building. One of the efforts to improve the quality of education is to make various innovations in education programs, among others; a) improving the curriculum, b) the procurement of books/teaching materials, c) improving the quality of teachers and education personnel through various training, d) improvement of education management, e) improvement of education facilities and infrastructure.

In Islamic educational institutions that play their role in Indonesia when viewed from the internal structure of Islamic education and educational practices, there are four categories. First, the boarding school education, which is traditionally held Islamic education, starting from the teachings of Qur'an and hadith and designing all education activities. Second, madrasah education, ie Islamic education held in Western model institutions that use classical teaching methods, and trying to inculcate Islam as a foundation of life for the students. Third, the general education that breathes Islam, ie Islamic education is done through the development of an atmosphere of education that breathes Islam institutionalized-educational institutions that organize educational programs that are general. Fourth, Islamic religious lessons are held in public education institutions as a subject or course. 
According to Zamakhsari (1983) the number of pesantren educational institutions throughout Indonesia in the past 2 decades developed very quickly. Counted in December 2008 has reached a quantity of 21,521 boarding schools with the number of santri as many as 3557,713 students. Previously Zamakhsari has described the number since 1977 amounted to 4,176 pesantren, in 1987 amounted to 6,579 pesantren. But for the next decade has not been shown a significant development. The new year 1997 begin to grow to 8,342 boarding schools, in 2000 as many as 14,666 pesantren.21 And 5 years later increased 6,855 pesantren so that the total of all pesantren in Indonesia amounted to 21,521 pesantren. The data above shows that boarding schools have experienced significant development in quantity aspect. Among the many factors that influence why the growth of pesantren is growing rapidly is because of the habit of santri who after completion or graduation from studying to a kyai, he is given permission for or diploma by kyai to open and establish new pesantren in his native area. In this way, the development of pesantren is more prevalent in various regions, in the homeland, especially in rural areas.

In the perspective of pesantren history is not only identical with Islamic meaning but also contains the meaning of authenticity of Indonesia (indigenous) pesantren is a continuing religious education institution of pre-Islamic religious education institutions, called mandala. It is said that this mandala has existed since the days before Majapahit and serves as a center of education (a kind of school) and religious. Mandala is considered by the Hindu-Buddhist as a holy place because there are only priests or ascetics who give the exemplary life of the surrounding community because of their piety. Mandala is also called as wanasrama led by siddapandita who hold muniwara, munindra, muniswara, maharsi, mahaguru or teacher deity.

Pesantren (Islamic Boarding School) now can be divided into two kinds, namely traditional pesantren (salaf) and modern pesantren. In the Modern Boarding School, or Modern Pesantren or commonly referred to as khalafiyah, 'ashriyah or al-haditsiyyah, is the opposite of salafi pesantren (salafiyah). There are no definitions and definite criteria of pesantren as a condition to be called a moderate pesantren.Although there are no definite criteria, some of the elements that characterize modern boarding schools are as follows: (1) Emphasis on foreign languages Arab and English in conversation. (2) Have a formal school under the curriculum of MoNE and/or Ministry of Religious Affairs of SD / MI MTS / SMP MA / SMA or high school. (3) The mastery or portion of the yellow book is lacking. (4) No longer using traditional recitation systems such as sorogan, wetonan, and bandongan. Use contemporary Arabic literature books (not classics / yellow books). Furthermore, the administrative system is similar to the formal school administration, such as registration with the selection system so that not all candidates are accepted, the entrance fee is generally higher than the salaf boarding school, and so on In terms of the quality of science: Arabic conversation fluently but lacking in the ability of mastery of literature of yellow book by salaf scholars and Arabic grammar, and the discipline of Islam (tafsir, science of hadith, fiqh, ushul fiqh and so forth) less than salaf pesantren.

The traditional pesantren education system is often called the Salafi system. It is a system that retains the teaching of classical Islamic books as the core of education in pesantren. Modern Islamic boarding school is an educational system that seeks to fully integrate traditional systems and formal school systems (such as madrasah). The purpose of the process of modernizing pesantren is to try to perfect the existing Islamic education system in pesantren. Recently boarding schools have new tendencies in order to renovate the system that has been used. Changes that can be seen in modern pesantren include: getting familiar with modern scientific methodology, more open to developments outside of itself, diversifying programs and activities in pesantren more open and widespread, and already functioning as a community development center.

In order for education in Indonesia to undergo a better change it is necessary to strive for consistent and systematic improvement of the educational paradigm that we build is education that can develop the potential of students to be brave to face the challenges of life as well as global challenges, without feeling depressed, our education must be able to encourage students to have the knowledge, skills, have high confidence and able to adapt quickly to the environment. This requires an educational pattern that is deliberately designed to equip learners with life skills, interactively combining generic and specific awareness to solve and overcome life problems. Education must be functional and clear the benefits for 
learners, so it is not merely a buildup of knowledge that is not meaningful. Education should be directed to the life of the students and not stop on the mastery of learning materials.

Given the people of Indonesia now has been in a new world order that is global. Where globalization is described by Giddens "... is a picture that the borderless world, capital, and all human labor can move rapidly from one country to another. Merentasi until eas of countries that once seemed insulated, until now seems to be a small village (small village) ". In addition, the advancement of information technology provides the widest space for human interaction very quickly. What happens in society on the Asian Continent can be enjoyed or witnessed by people in other parts of the world; Continental Europe or Africa, over an almost simultaneous period through; social media such as Facebook, Twitter, Instagram, Whatsup, Telegram and so on android based applications. Thus we have been in postmodernism.

Defining the notion of a postmodern society into an operational definition is not an easy task considering that the postmodern term itself represents a sporadic condition of social life that is so complex and abstract. The postmodern term itself is very confusing and even at one point so dubious it may be a situation, a condition, a theory, a philosophical flow or nothing more than a worldview and way of thinking to social realities through thousands of criticism and blasphemy to the condition of society modern without being able to provide a way out of sporadic situations that ensnare individuals in alienation due to the instability of the marker system displayed in the language medium. (https://www.kompasiana.com. Accessed April 15, 2018).

To provide clarity with regard to the great ambiguity of what is actually meant by the postmodern term, it is necessary first to distinguish what is the social theory of postmodernity, postmodernism, and postmodern. The term post modernity refers to a period, time, period and socio-political conditions that usually appear to accompany the modern era in a historical sense. Postmodernism refers to cultural products in art, film, architecture, and so on that look different from modern cultural products. While postmodern social theory refers to the form of social theory that is different from a modern social theory. So the postmodern term as a whole includes a new historical epoch, new cultural products, and a new type of theorizing about the social world in today's society. In this case, postmodernism as a discourse of thought must be distinguished from postmodernity as a social reality. Post modernity is a condition where society is no longer governed by the principle of production of goods but is controlled by the production and reproduction of information that causes everything to be in an unstable condition and difficult to distinguish between real and unreal while postmodernism is the discourse of new thinking as the antithesis of modernism offering promises of order, rationality, efficiency, certainty, and democracy. One form of technological advances and information born in the post-modern era is Android. Actually, Android is a Linux-based operating system designed for touch screen mobile devices such as smart phones and tablet computers.Android was originally developed by Android, Inc., with financial support from Google, which was later purchased in 2005. The operating system was officially released in 2007, in conjunction with the establishment of the Open Handset Alliance, a consortium of hardware, software, and telecommunications that aim to advance the open standards of mobile devices.

According to Markoff "Android, Inc. founded in Palo Alto, California, in October 2003 by Andy Rubin (founder of Danger), Rich Miner (founder of Wildfire Communications, Inc. Nick Sears (former VP of T-Mobile), and Chris White (head of WebTV interface design and development) to develop "smart mobile devices that are more aware of their location and user preferences (Elgin, 2005)".

The initial goal of Android development was to develop a sophisticated operating system for digital cameras, but it was later realized that the market for the device was not large enough, and Android's development was diverted for the Smartphone market to compete with Symbian and Windows Mobile (Apple iPhone has not yet been released on at that time, Chris Welch 2013). Although Android developers are experienced technology experts, Android Inc. operated secretly, only disclosed that the developers are creating a software that is destined for mobile phones... Still, in the same year, Rubin ran out of money. Steve Perlman, a close friend of Rubin, lent him $\$ 10,000$ in cash and refused a stock offering in the company (Elgin, 2005). 
The existence of the above technology allows for the development of a virtual pesantren. They are pesantren located in cyberspace, but the tri-center education component (Kiyai, Pondok and Santri, and the community), can interact intensively which is not limited by country, time and cost. It's just that the cottage in the physical sense of learning buildings, mosques and so on is not present in the real form. Furthermore, this study would like to examine: Is there a correlation between public perception and public figure about pesantren $\mathrm{n}$ post-modern android based ?. This becomes important considering the existence of our society who have been accustomed to using android applications as a media technology. While the learning of religion is formally constrained by the busyness done by the community. So the virtual pesantren is an alternative pesantren development that may be run. With this research is a pioneering research that does not focus on the application of android technology, but how the readiness of society to face social changes faster as the technological advancement continues to grow rapidly. The aims of the research were : (1) to describe the perception of community about post modernism pesantren (virtual pesantren) based on Android. (2) To describe about Islamic Scholar perception about post modernism (virtual pesantren) based on Android. (3) To find the correlation between public opinion (community) and Islamic Scholar about post modernism pesantren (virtual pesantren) based on Android.

\section{Methods}

This study uses a quantitative approach. Population in this research is Padang city society (especially in District of Padang Utara). The sample of research is 128 people and 30 community leaders (AlimUlama) people. The sample selection was done in a simple random (The sampling technique is done because the population has a clear unit of analysis that is in the form of population data owned by North Padang Sub district). Data collection techniques using questionnaires. The questionnaire is a technique of data collection by asking written questions to be answered in writing also by respondents. The questionnaire is a collection of written questions that are used to obtain information from respondents about themselves or things that he knew. The purpose of spreading the questionnaire is to find complete information about a problem and respondent without worry if respondents give answers that do not fit with the fact in filling out a list of questions. In addition, respondents know certain information.Data analysis technique by using SPSS program version 24. The technique of statistical analysis used Pearson Correlation. The Pearson correlation is one of the correlation measures used to measure the strength and direction of the linear relationship between the two variables. Two variables are said to be correlated if changes in one variable are accompanied by changes in other variables, either in the same direction or the opposite direction.

\section{Results and Discussion}

(1) Descriptive analysis of respondents and spreading of mean data of variables. (2) The quantitative analysis and testing of the hypothesis. The Descriptive Analysis of Respondent mention below:

Table 1: The Descriptive Analysis of Respondent

\begin{tabular}{llcc}
\hline \multicolumn{1}{c}{ The Categories } & Frequencies & Percentage \\
\hline $\mathbf{1}$ & The Education level & & \\
& First Degree & 95 & 60.13 \\
& post Graduate & 63 & 39.87 \\
& Sum & 158 & 100.00 \\
$\mathbf{2}$ & & \\
& Ages & 84 & 53.16 \\
& 20 - 40 years old & 74 & 46.84 \\
& 41 - 60 years old & 158 & 100.00 \\
Sum & & \\
The family social-organization backgr & 87 & 55.06 \\
& Muhammadiyah & 46 & 29.91 \\
\hline
\end{tabular}




\begin{tabular}{lcc}
\hline Exactly & 25 & 15.03 \\
Sum & 158 & 100.00 \\
\hline
\end{tabular}

Source s: The research reports 2017

According to Table 1, we found that most of the respondents at Darul Ma'rifat studied at First-degree level $(60.13 \%)$. Then, most of the ages of respondents were between $20-40$ years old $(53.16 \%)$. The research Also found that most of the social-organizational family background was Muhammadiyah (5 5 $.06 \%$ ). Then, according to the mean and spreading of frequencies and percentage of the pesantren virtual idea had shown below:

Table 2 : The Mean Spreading, Frequency and Percentage of Perception Community about Virtual Pesantren

\begin{tabular}{lcc}
\hline The Categories & Frequenc ies & Percentages \\
\hline Low & 39 & 30.47 \\
High & 89 & 69.53 \\
\hline Sum & $\mathbf{1 2 8}$ & $\mathbf{1 0 0 . 0 0}$ \\
\hline
\end{tabular}

Sources: The research reports, 2017

According to the Table 2 above, most of the mean spreading was located at the high level $(69.537 \%)$ and only ( $30.47 \%$ ) were categories low. It means that the majority of people thought the virtual pesantren is one of the challenges in the new era (information and technology) The virtual boarding school was possible for us to implement. But, we have to think about how to realize that in a social context. Because pesantren have a normative model in our community. Then, the people always think about pesantren in the normative standard. The Kiyai / Buya should interact directly with the students. On the other hand, the mean spreading frequencies and percentages of Islamic Scholar perception about virtual pesantren has shown below:

Table 3 : The Mean Spreading, Frequency and Percentage of Islamic Scholar Perception of Virtual Pesantren Based on Android

\begin{tabular}{ccc}
\hline The Categories & Frequenc ies & Percentages \\
High & 8 & 26.67 \\
Low & 22 & 73.33 \\
\hline Sum & $\mathbf{3 0}$ & $\mathbf{1 0 0 . 0 0}$ \\
\hline Sources: The research reports, 2017 & &
\end{tabular}

According to the Table 3 above, most of the mean spreading were located at the low level $(73.33 \%)$ and only $(26.67 \%)$ was located at a high level. It means that the Islamic Scholar did not agree to implement of virtual pesantren. They think that virtual pesantren will make the relation between Islamic Scholar (Kiyai / Buya) with the students (santri) have a gap. Actually, the relation between the Kiyai / Buya with the santri is the essential one. The students got a blessing from their Kiyai / Buya. Besides that, the cottage or the place that the students stay should exist and the mosque is also a very important one for the pesantren. They conclude that virtual pesantren cannot be implemented, although the reality has been changed. Hypothesis analysis had presented below:

Table 4 : The Hypothesis Analysis

\begin{tabular}{llll}
\hline & & $\begin{array}{l}\text { Community } \\
\text { Perception }\end{array}$ & $\begin{array}{l}\text { Islamic Scholar } \\
\text { Perception }\end{array}$ \\
\hline Community Perception & Pearson Correlation & 1 & .042 \\
& Sig. (2-tailed) & & .000 \\
& N & 158 & 158 \\
& Pearson Correlation & .042 & 1 \\
Islamic Scholar Perception & Sig. (2-tailed) & .000 & \\
\hline
\end{tabular}


** Correlation is significant at the 0.01 level (2-tailed).

According to The table 4 above, we got information that $\mathrm{r}_{\text {score }}=0.042 .<\mathrm{r}_{\text {table }}=0.176$, and $\mathrm{p}=000$ $<0.05$. $\mathrm{H}_{\mathrm{o}}$ was accepted and rejects $\mathrm{H}_{1}$. So, there was no correlation between the perception of society and of Islamic Scholar about virtual pesantren based on Android. The community just thinking that virtual pesantren based on Android as practical, then with the pragmatism, because we had been in the third wave as Tovller said before. But the Islamic Scholar think that virtual pesantren made a person relation (Islamic Scholar ; Kiyai / Buya) and their students were not in the proper condition. Then, virtual pesantren eliminate mosque and pondok as an important aspect about pesantren.

The most phenominal historical fact, which shows the existence of modernization and innovation in various aspects is the progress achieved by Islamic education in classical times. From the halaqah system with the material focusing on the religious sciences, to the madrasah system that developed in the 8th century $\mathrm{AD}$, up to the 14th century $\mathrm{AD}$, where Muslims reached the pinnacle of world civilization and unmatched by other nations of the world, including West. The spectacular leap of Muslim civilization came after Muslim scholars cultivated and developed the results of classical Greek science and technology. At that time emerged a large and famous Islamic educational institutions, among others; Madrasah Nizamiyah in Baghdad, Baitul Hikmah, Cordova University in Andalusia, AlAzhaar University in Cairo-Egypt. Also born at the time were the great names of Muslim philosophers and scholars such as Ibn Sina, Al-Kindi, Al-Farabi, Al-Ghazali, Ibn Rusy, Ibn Tufail, Ibn Majah, AlKhawarizmi and Jabir Ibn Hayyan with his works in medicine, chemistry, mathematics, philosophy, tasawwuf and other works.

Departing from the great history of Islamic education and civilization of the past, not as dwarf Muslims in the face of global challenges. Muslims must and must come out from behind. Muslims must equip themselves with the capabilities needed by the industry. Muslims are obliged to learn new methods of learning and education systems in order to be born competent generations in the future. Allah SWT encourages His people to make changes, as it is said in the Qur'an; "Allah will not change the state of a people so that they change the state that is in themselves" (Q.S. Ar-Ra'd: 13: 11). The above verses are life choices for the people, whether to stand at one point (static), or to move dynamically innovate the renewal and modernization in various aspects of life. So that the future pesantren can break away from the bad stigma as educational institutions slum, old-fashioned, old-fashioned, traditional and stagnant.

Considering such complex global challenges, pesantren is the time to take on the role and function of agent of change, agent of culture and agent of knowledge, to rebuild the Islamic education system so as to enter the cultural, theological and philosophical space of humanity as a whole. It is the Islamic educational system which is insightful Ulu al-Albab (Surah Ali Imran, 3: 189-190), who is always busy remembering God while sitting, standing and lying down; and busy contemplating His creation in heaven and on earth, both in the day and in the night. Or educational system oriented to the formation of intellectual cociaty, where they are expected to be able to carry the "cultural revolution" in a comprehensive manner.

In order for the pesantren to come forward, to borrow his language Yudian Wahyudi, not to commit "suicide of civilization", he must improve the Islamic education system with the future global trend. First, Muslims must be able to utilize technology as a means of struggle (jihad). That is, the means of technology should be used as a tool for the struggle of Muslims in improving the quality of education, and not vice versa as a barrier to creativity thinking and doing for change for progress. Secondly, Muslims must continually improve quality human resources and science simultaneously, or increase themselves toward spiritual, moral and intellectual strength. Third, the process of modernization is something that is necessary for the reform of the Islamic education system, starting from the paradigm, concept, framework and evaluation. That is, the entire academic community of Islamic education should have a sense of depelopment to a better direction, so that Islamic education institutions in the future will be a future laboratory harmony (http://www.republika.co.id, Uploaded April 2nd , 2013). 
Departing from the various explanations above shows that, education in Pondok Pesantren need to continue to innovate and be creative and dynamic in the face of change. Nevertheless what we want to underline in this research is not only teaching methods that need to use Information Computer Technology (ICT) alone. But it also provides opportunities for the formation of a new educational model in which pesantren no longer requires land to establish pesantren, limited teaching in the classrooms, or ICT teaching methods applied in the course. But it is possible to establish an Androidbased virtual boarding school. Where Android became the main media in the process of moving the wheels of the pesantren. Furthermore, the fact also shows that in Indonesia alone there are some pesantren virtual schools that manage Arabic teaching and study preparation to the Middle East, especially Saudi Arabia. This is evidenced through the virtual presence of pesantren namely; Al Madinah Islamic Boarding School www.pesantrenalmadinah.com). Based on this analysis, pesantren has similar challenges and constraints, among others; 1) The difference in the background of the pesantren of the educators and their caregivers, 2) the low average of religious education, 3) the lack of qualified teachers, 4) the lack of facilities and infrastructure, and 5) the cost of education depends on the payment of santri.

Therefore, the leadership of the hut and other steak holder need to open a discussion room on the curriculum change and need to take productive steps based on swot analysis that has been done before, for example 1) Innovate the curriculum and all the components that accompany it, 2) restructure the development, especially the Directorate of Education and Teaching, 3) Re-selection of educators in accordance with required competencies, 4) Setting up a new, humanistic, integralistic and comprehensive ICT-based learning method with the application of problem-solving education, education of exemplary (behaviouristik) by maintaining the tradition that became the spirit and characteristics of pesantren that refers to the Qur'an and hadith.

Departing from the various explanations above shows that, education in Pondok Pesantren need to continue to innovate and be creative and dynamic in the face of change. Nevertheless what we want to underline in this research is not only teaching methods that need to use Information Computer Technology (ICT) alone. But it also provides opportunities for the formation of a new educational model in which pesantren no longer requires land to establish pesantren, limited teaching in the classrooms, or ICT teaching methods applied in the course. But it is possible to establish an Androidbased virtual boarding school. Where Android became the main media in the process of moving the wheels of the pesantren. Furthermore, the fact also shows that in Indonesia alone there are some pesantren virtual schools that manage Arabic teaching and study preparation to the Middle East, especially Saudi Arabia. This is evidenced through the virtual presence of pesantren namely; Pondok Pesantren Al Madinah (www.pesantrenalmadinah.com). The other example about virtal pesantren is www.pesantrenvirtual.com is tracked by us since April, 2011. Over the time it has been ranked as high as 147899 in the world, while most of its traffic comes from Indonesia, where it reached as high as 6 598 position. Then, www.pesantrenalirsyad.org ; www.pesantren.web.id ; www. pesantrenkaligrafipskq.com; www. pesantrentahfidzmataqu.com; www.pesantren.info. Future more,

\section{Conclusion}

The conclusion of the study found: (1) the community views that social change, in which technology allows for the development of Android-based virtual pesantren. Thus, pesantren education has a wide influence not only in Indonesia and even throughout the world. (2) Islamic Scholar viewed that, pesantren should have tri education center (Kiyai/Buya), pondok and santri, the community. So virtual pesantren in the postmodernism era is not eligible to be declared an educational institution of pesantren. (3) There is no correlation between public opinion and religious figures (about the development of virtual pesantren based on Android in postmodernism decade). The important issue of concern is how to format the implementation that is appropriate for the android-based virtual pesantren. Based on local culture that has diversity of Islamic belief. Given the many organizations that grew and evolved as civilization progresses from society itself. Recommendations: There needs to be a more indepth study of the development of Android-based pesantren at the empirical level; curriculum, learning system, learning strategy and assessment mechanism and so on. 


\section{References}

Android Overview. (2017). Open Handset Alliance. (Accessed on 2018 -07-15).

Chris Welch. (2013). "Before it took over smartphones, Android was originally destined for cameras". The Verge. (Retrieved dated 2018-08-01).

Depag., Life Skill Integration Guideline on Learning, Jakarta: Dirjend Islamic Institution, 2005

Elgin, Ben (August 17, 2005). "Google Buys Android for Its Mobile Arsenal". Bloomberg Businessweek. Bloomberg. Archived from original version dated February 24, 2011. Retrieved dated 2018 -02-20. In order to be a key move in its nascent wireless strategy, Google (GOOG) has quietly acquired the startup of Android, Inc.

Faisal Ismail (2003). Masa Depan Pendidikan Islam di Tengah Kompleksitas Tantangan Modernitas, Jakarta : PT. Bhakti Aksara Persada.

Ismawati, (2004). "Tracing the Forerunner of Javanese Pesantren", in Anasom (ed), Re- formulating Interrelation of Islam-Java. Yogjakarta: Gama Media Publisher and Islamic Studies Center and Buda ya Java IAIN Walisongo Semarang.

Markoff, John (November 4, 2007). "I, Robot: The Man Behind the Google Phone". The New York Times. Accessed on 2018 -07-25.

Reza Fahmi and Prima Aswirna. (2013). The Character Building In Islamic Boarding School And Peaceful Thinking Of Students At Darussalam Islamic Boarding School (Gontor) In Ponorogo, East Java. Proceeding at the International Symposium held by Dept. of Religious Affairs: Bogor 2012.

Reza Fahmi. (2012). Empowering Madrasa Through Small and Medium Industry (Study at Darul Ma'rifat Modern Islamic Boarding School in East Java). Jakarta: Proceeding at International Symposium held by Religious Affairs Dept. of Indonesia

Reza Fahmi. (2015). Social Prejudice and Rebellian Behavior of Students at Gontor Modern Islamic Boarding School in East Java. Journal of Migration Research and Development (IJMRD). www.ijrmd.info. (OJS).

Reza Fahmi. (2018). The Descriptive Study about Personality Character and Self-fulfillment of Students (Study at Gontor Darul Ma'rifat Islamic Boarding School, Kediri East Java). Proceedings. of International Conference on Education, Social Science and Technology (ICESST) Padang: State University of Padang. ( March $20^{\text {th }}$ 2018).

Reza Fahmi. (2018). Development of Self-Empowerment Module Based on Entrepreneurship Learning at Pondok Pesantren Gontor Darul Ma'rifat, Kediri East Java. tt. Dissertation. Padang: State University of Padang. Page 13.

Reza Fahmi. (2018). The Edducational Tourism and Self-fulfillment of Students (Study at Gontor Darul Ma'rifat Islamic Boarding School, East Java - Indonesia). Proceeding. International Conference on Tourism: Malaysia: Institute of International Islamic Thought (IIIT), University Technology Malaysia and Minestry of Tourism Malaysia.

Yasmadi, MA, Modernization (2005). Pesantren (Nurcholish Madjid Critique of Traditional Islamic Education), Jakarta: Quantum Teaching.

Zamakhsari Dhofier. (1982). Pesantren Studies on the Living View of Kyai, Jakarta: LP3ES.,

Zarkasyi, Abdullah Shukri. (2002). The Role of Religion and Islamic Culture in Encouraging the Change of Science and Technology (A Model from Pondok Modern Darussalam Gontor), National Seminar Paper "Implementation of Qur'anic Acts". Committee MAN-V, PT Telekomunikasi Indonesia Tbk, (Bandung, 23 April 2002). 